\title{
Liquidity Benefits from IPO Underpricing: Ownership Dispersion or Information Effect ${ }^{*}$
}

\author{
Nesrine Bouzouita ${ }^{\mathrm{a}}$, Jean-François Gajewski ${ }^{\mathrm{b}}$, and Carole Gresse ${ }^{\mathrm{c}}$ \\ ${ }^{\text {a }}$ Université Paris-Dauphine, DRM \\ e-mail: nesrine.bouzouita@dauphine.fr \\ ${ }^{\mathrm{b}}$ Université de Savoie, IREGE, IAE Savoie Mont-Blanc \\ e-mail: gajewski@univ-savoie.fr \\ ${ }^{\mathrm{c}}$ Corresponding author - Université Paris-Dauphine, DRM \\ e-mail: carole.gresse@dauphine.fr
}

June 2012

JEL classification: G12, G14, G32

Keywords: IPO, initial underpricing, ownership structure, post-listing liquidity, information asymmetry, analyst coverage

\footnotetext{
* We gratefully acknowledge financial support from ECMI. We are thankful to Ali Akyol, Noël Amenc, Olivier Brandouy, Hsin-Hui Chapman, Serge Darolles, Edith Ginglinger, Dimitrios Gounopoulos, Steven Jones, Petko Kalev, Bill Megginson, Hélène Rainelli, Ronnie Sadka, Fabrice Riva, and participants at the 2008 FMA meetings in Orlando, the 2008 FMA European meetings in Prague, the 2008 AFBC in Sydney, the 2012 FMA European meetings in Istanbul, the AMF scientific board seminar, and seminars at the universities of Grenoble, Paris-Est Créteil, Paris-Dauphine, Paris-Panthéon Sorbonne, for insightful comments on earlier versions. Any new comment is welcome.
} 


\title{
Liquidity Benefits from IPO Underpricing: Ownership Dispersion or Information Effect
}

\begin{abstract}
Our study investigates by which channels IPO underpricing impacts post-listing liquidity. Using a sample of IPOs undertaken on Euronext with diverse mechanisms, we show that when ownership structure is not influenced by initial underpricing, this underpricing still has a positive impact on aftermarket liquidity by a virtuous cycle related to analyst coverage. The analyst coverage purchased by initial underpricing reduces information asymmetry costs and illiquidity in the secondary market. The public information produced by analysts has a statistically more significant impact on adverse selection costs than on the proportion of informed traders in the market.
\end{abstract}




\section{Introduction}

The vast majority of empirical studies examining the liquidity of recently listed stocks support the notion that initial public offering (IPO) underpricing boosts secondary market liquidity. On average, underpriced IPOs exhibit higher aftermarket trading activity than overpriced IPOs (Miller and Reilly, 1987; Hanley, 1993; Schultz and Zaman, 1994; Reese, 1998; Hahn and Ligon, 2006; Li and Zheng, 2008). A higher level of underpricing leads not only to increased trading turnover but also to lower bid-ask spreads (Pham, Kalev, and Steen, 2003; Li, Zheng, and Melancon, 2005) and lower adverse selection costs (Li, McInish, and Wongchoti, 2005). ${ }^{1}$ However, apart from Pham et al. (2003), no literature exists on how this positive link between initial underpricing and liquidity actually is formed. We aim to help fill this gap in understanding.

In accord with the theory of Booth and Chua (1996), referred to as the ownership dispersion hypothesis in the remainder of this paper, Pham et al. (2003) find that the positive relation between initial underpricing and post-listing liquidity is formed through the mediation of a broader ownership structure resulting from the allocation process. In this article, we propose that while there may be markets in which ownership concentration is insensitive to IPO underpricing, this underpricing still has a positive impact on post-listing liquidity due to the information effect of analyst coverage engendered by underpricing. This theoretical interpretation of our empirical evidence is based on: (a) the models by Chemmanur

\footnotetext{
${ }^{1}$ The only exception in this literature is the article by Ellul and Pagano (2006). They demonstrate that initial underpricing can be an increasing function of the expected post-listing illiquidity due to asymmetric information and they provide empirical evidence in support of their theory using a sample of IPOs in the UK.
} 
(1993) and Aggarwal, Krigman, and Womack (2002), which show that initial underpricing attracts analyst coverage, and (b) the observation that analyst and financial media coverage reduces information asymmetry and thus illiquidity (cf. Reese, 1998; ${ }^{2}$ Popescu and $\mathrm{Xu}$, $\left.2011^{3}\right)$. This theory is further referred to as the information production hypothesis.

The main contribution of our research is to depart between the ownership dispersion and the information production hypotheses, and to find evidence in support of the latter, by exploiting IPO data, intraday market data, ownership data, and analyst coverage data for a sample of IPOs undertaken on Euronext Paris between 1995 and 2008. Like most previous papers, we show that post-IPO liquidity increases with initial underpricing. We find that adverse selection costs and informed trading are lower for more underpriced IPO stocks, which suggests that more public information is produced for these stocks. In contrast with the theory of Booth and Chua (1996) and the findings of Pham et al. (2003), we fail to prove that these effects result from a more diffuse ownership obtained by underpricing the issue. Instead, we show that these results are due to enhanced analyst coverage of IPOs that perform well in the immediate aftermarket, as argued in Aggarwal, Krigman, and Womack's (2002) model. We provide evidence that secondary market information asymmetries are reduced and postlisting liquidity is enhanced through analyst coverage unleashed by initial returns.

We also contribute to existing literature in other ways. First, many of the empirical studies that find a positive link between IPO underpricing and post-listing liquidity are based

\footnotetext{
${ }^{2}$ Reese (1998) assigns the positive relation between underpricing and post-listing liquidity to financial media coverage which reduces information asymmetry.

${ }^{3}$ Popescu and $\mathrm{Xu}$ (2011) shows that some characteristics of the underwriting syndicate as well as the number of analyst recommendations are associated with lower spreads and lower information asymmetry after the primary listing.
} 
on daily trading volumes only whereas we adopt a microstructure approach as in Pham et al. (2003) and Ellul and Pagano (2006). Trading volumes are complemented with other liquidity measures based on daily data, and for continuously traded securities, we also use spreads and information asymmetry metrics. Second, in contrast to U.S. samples, which are composed only of book-built IPOs, our sample is diversified in terms of IPO mechanisms and includes not only pure book-buildings, but also mixed book-buildings, auctions, and fixed-price offers. This also differs from Pham et al.'s (2003) study, where the sample was composed mainly of fixed-price offers. The diversity of our sample in terms of issuing procedures ensures that our findings are not driven by the specifics of a given issue mechanism and allows us to compare book-built IPOs with others. Third, we examine IPO stocks traded in an order-driven market whereas most U.S. studies are based on Nasdaq IPOs for which the secondary market has a dealership structure. This is also the case for Ellul and Pagano's sample in the UK. The results of such studies may, therefore, be due to the market-making role that underwriters can play in this type of market after the listing.

The remainder of the article is organized as follows: Section 2 presents the testable hypotheses. Section 3 describes the institutional settings, the sample, and the data. Empirical measures are laid out in Section 4. Sections 5 and 6 respectively present the methodology and the results. Several robustness checks are conducted in Section 7. Section 8 concludes.

\section{Testable hypotheses}

Two theories are considered to explain why initial underpricing would enhance aftermarket liquidity. One explanation is that underpricing an IPO is a way of attracting more shareholders, as demonstrated by Booth and Chua (1996). The more dispersed ownership obtained by underpricing the issue would then result in a more liquid secondary market. We refer to this theory as the ownership dispersion hypothesis. A second possible explanation is 
based on the information models developed by Chemmanur (1993) and Aggarwal et al. (2002). They showed that initial underpricing attracted analyst coverage. Reese (1998) also found that the level of interest in a firm measured by newspaper references was positively related to initial return, initial trading volume, and long-term trading volume. We propose that when initial underpricing attracts press and analyst coverage, more public information is produced about the firm which may reduce information asymmetry in the secondary market and thereby improve liquidity. We refer to this theory as the information production hypothesis.

\subsection{The ownership dispersion hypothesis}

While some IPO candidates may desire a concentrated ownership to confer greater monitoring power to pre-IPO or new large shareholders, others may want a diffuse ownership structure in order to obtain higher secondary-market liquidity, a factor often considered as an important criterion of success of an IPO (Corwin, Harris, and Lipson, 2004). Indeed, firms with more dispersed ownership generally have a more liquid stock market (Brockman, Chung, and Yan, 2009; Ginglinger and Hamon, 2007; Heflin and Shaw, 2000), and this presents several advantages. A more liquid secondary market can make corporate governance more effective (Maug, 1998). In general, higher aftermarket liquidity contributes to increasing the firm's value and reducing its cost of capital in several ways. It improves the issuing firm's future access to capital markets, namely by attracting investors, reducing transaction costs in future equity raisings (Ibbotson and Ritter, 1995), and lowering gross fees requested by investment banks in subsequent equity offerings (Butler, Grullon, and Weston, 2005). It also reduces the illiquidity premium and thus the returns required by investors to hold the firm's shares (Amihud and Mendelson, 1986; Brennan and Subrahmanyam, 1996). 
Booth and Chua (1996) demonstrated that IPO firms seeking secondary-market liquidity underpriced their stock in order to attract a large number of small shareholders and create a more dispersed ownership structure. Consistent with this theory, Michaely and Shaw (1994) and Brennan and Franks (1997) found higher underpricing for IPOs with a more diverse shareholder base. In this study, we test Booth and Chua's (1996) theory by examining not only the relation between initial underpricing and ownership dispersion, but also the subsequent effect of ownership dispersion on post-listing liquidity. These testable hypotheses are expressed as follows:

H1a. ownership dispersion increases with initial underpricing;

H1b. the ownership dispersion generated by initial underpricing contributes to increasing the liquidity of the IPO stock in the secondary market.

\subsection{The information production hypothesis}

The idea that attracting information production would be a motivation for underpricing IPOs was first developed by Chemmanur (1993) in a theoretical model. In this model, firm insiders, who have private information about their firm's prospects, sell equity both in the new issues market and in the secondary market, and outsiders may engage in costly information production about the firm. Underpricing results from the insiders of high-value firms inducing information production in order to obtain a more precise valuation of their firm in the secondary market. Initial returns compensate outsiders for the cost of producing information and this information results in a higher stock price for high-value firms in the secondary market.

In accord with Chemmanur's theory, several papers (Rajan and Servaes, 1997; Bradley, Jordan, and Ritter, 2003; Cliff and Denis, 2003; Francis, Hasan, Lothian, and Sun, 2010) have found evidence for a positive link between initial underpricing and analyst coverage measured 
by the probability of coverage or the number of covering analysts. For Cliff and Denis (2003), IPO underpricing would be a way of compensating analysts for their efforts to collect information.

Aggarwal et al. (2002) developed another model of IPO underpricing with information production by considering that insiders are restricted by lock-up agreements. In their model, managers strategically underprice their IPOs to maximize personal wealth from selling shares at lock-up expiration. Initial returns generate information momentum by attracting attention to the stock and thereby shifting the demand curve up. This allows managers to sell shares at higher prices at the expiration of the lock-up period.

From this literature, we derive three testable hypotheses based on the argument that the information momentum created by underpricing a new issue may contribute not only to increasing the stock price but also to improving stock liquidity in the secondary market due to increased interest in the stock and reduced information asymmetry. Those hypotheses are stated as follows:

H2a. initial underpricing attracts public information production on the firm following its IPO;

H2b. the information production generated by initial underpricing contributes to increasing the liquidity of the IPO stock in the secondary market;

H2c. the information production generated by initial underpricing contributes to reducing the information asymmetry on the IPO stock in the secondary market.

\section{Institutional settings, sample, and data}

The above-mentioned hypotheses were tested on a sample of IPOs undertaken on Euronext Paris between 1995 and 2008 about which we hold exhaustive data. 


\subsection{Institutional settings}

During our sample period, Euronext Paris was restructured. Prior to 2005, it was organized into three regulated market segments: the Premier Marché designed for the listing of large companies, the Second Marché that catered to medium and small companies, and the Nouveau Marché for growth companies. In 2005, Euronext Paris merged the Premier Marché and the Second Marché into a single segment, Eurolist, and the Nouveau Marché was closed and replaced by Alternext. Before 2005, most IPOs took place either in the Second Marché or in the Nouveau Marché. Since 2005, they have been distributed evenly between Eurolist and Alternext.

For any new listing, the specificity of Euronext Paris' primary market is to offer and handle a panel of initial offering mechanisms ${ }^{4}$ comprising a fixed-price offering procedure, a book-building procedure called placement, and three auction mechanisms (direct admission, minimum price offer and open-price offer) in which Euronext is the auctioneer. Fixed-price offer and open-price offerings can be associated with a placement. In fact, most book-built issues are offered as a double-stage issue whereby, in addition to the private book-building process, a separate mechanism offers shares to the public. The simplest and most common technique is to offer shares to the public at a fixed price which is equal to the equilibrium price set during the book-building process. An alternative method is to organize an auction in which individual investors can place limit orders. In this case, the issue price may differ for each category of subscriber. Under Euronext regulations, the issue price paid by institutions in the book-building process may not be lower than the definitive public offer price.

\footnotetext{
${ }^{4}$ For a detailed description of these listing mechanisms, see Gajewski and Gresse (2006).
} 
Euronext's secondary markets are all order-driven, yet some trading designs differ according to the market segment and the liquidity of the stock traded. For most liquid stocks, order book trading is continuous, with the trading session commencing and terminating with batch auctions. For less liquid securities, trading is only periodic, with one or two batch auctions a day. In addition, for some securities, Liquidity Providers (LP) may act as market makers inside the order book. LPs are brokerage firms that signed a commercial agreement with NYSE-Euronext to provide liquidity on an instrument. Their role is to: (1) protect against variations in volatility; (2) guarantee transactions at the best price at all times; (3) support the volume of transactions in the order book. They are required to quote two-way bid and ask prices with a minimum volume size at all times during the trading session, fifteen minutes before the opening session, and in batch auctions. In compensation, they are not required to pay trading fees on market-making services. LPs mainly concentrate on small and medium capitalization stocks. For these equities, the agreement with the exchange is often (and always for IPO stocks) combined with a liquidity contract whereby the issuer hires the corporate broker not only to improve the market quality of its stock but also provide corporate services such as listing sponsorship and research.

Regarding the growth market segment, Alternext has a hybrid market structure similar to that of the Nouveau Marché before 2005. Two batch auctions are run per day. At the same time, market makers actively participate in the auction procedures and also supply liquidity on a continuous basis between auctions. 


\subsection{Sample and data}

This empirical study was conducted using data from four sources. First, we gathered the prospectuses available in the $\mathrm{AMF}^{5}$ database for IPOs undertaken on Euronext Paris during the period 1995-2008. After excluding transfers and listings of foreign companies, we obtained a sample of 358 IPOs for which we retrieved post-IPO closing prices from Datastream, high-frequency data from the Euronext Database, press coverage data from FACTIVA, and analyst coverage data from I/B/E/S detail history, covering the six months following the IPO. Matching these databases left us with a sample of 326 IPOs. Using their prospectuses, we retrieved the IPO date, the subscription price, the number of shares on sale in the IPO, the number of shares issued in and outstanding after the IPO, the IPO allocation mechanism, the underwriters' identity, the involvement of venture capitalists, and the percentage of shares held by the managers, members of their families, and blockholders before and after the IPO.

Of the 326 IPOs constituting the final sample, 171 were undertaken in the Second Marché or Eurolist and 155 took place in the Nouveau Marché or Alternext. In terms of IPO mechanisms, 275 issues involved a book-building process, 42 were auctioned and 9 were fixed-priced. Among the 275 book-built IPOs, 14 were exclusively book-built, 153 were associated with an auctioned public offer, and 108 were followed by a fixed-priced offering. All of the auctioned and fixed-price IPOs in the sample were undertaken in the 1990s, whereas the IPOs conducted during or after 2000 all used a mixed mechanism which associated the book-building process with either an auction or a fixed-price offer.

\footnotetext{
${ }^{5}$ Autorité des Marchés Financiers.
} 


\section{Empirical measures}

This study is based on five categories of empirical measures: IPO initial returns, lowand high-frequency liquidity metrics, information asymmetry measures based on intraday data for continuously traded stocks, ownership dispersion indices, and information production measures.

\subsection{Initial underpricing}

For each stock in the sample, underpricing is measured as the return between the closing price observed five business days after the IPO and the IPO price, and adjusted for the SBF 250 index return: ${ }^{6}$

$$
U_{1 w}=\frac{P_{5}}{P_{0}}-\frac{I_{5}}{I_{0}},
$$

where $P_{5}$ is the closing price on the fifth business day following the IPO; $P_{0}$ is the IPO price; $I_{5}$ is the closing value of the SBF 250 index on the fifth day following the IPO; and $I_{5}$ is the closing value of the index on the day of the IPO. The IPO is underpriced when $U_{1 w}>0$ and overpriced when $U_{1 w}<0$.

Studies of U.S. samples generally measure IPO underpricing over the first day of trading, assuming that the post-listing equilibrium price is reached at the first close. In contrast with these studies, we retain a five-day horizon to measure initial underpricing. The statistics presented in Table 1 show that mean underpricing is around $2.80 \%$ over the first day of trading, $15.63 \%$ one week after the IPO, and $20.06 \%$ one month after. We thus consider

\footnotetext{
${ }^{6}$ The SBF 250 is a stock index of Nyse-Euronext that comprises the 250 largest capitalization stocks of Euronext Paris. It includes large, mid, and small caps and it is the most representative index of the French stock market.
} 
that post-IPO prices take longer than one day to stabilize on Euronext and that a five-day horizon is more appropriate.

\subsection{Liquidity measures}

Liquidity is measured over the six-month period that starts five trading days after the IPO date. This five-day gap is meant to eliminate the effect of the abnormal trading activity generally observed in the first days following a primary listing. Among the 326 IPOs in our sample, 154 were traded continuously during the 6-month observation period. The remaining 172 stocks were traded in batch auctions only (one or two per day).

For the entire sample, post-IPO liquidity is measured with the average daily turnover, Amihud's (2002) illiquidity ratio, and the zero-return ratio of Lesmond, Ogden, and Trzcinka (1999). The average daily turnover, denoted $T U R N$, is the average daily volume in percentage of the number of shares sold in the IPO. Amihud's (2002) illiquidity ratio is an estimate of the sensitivity of prices to traded quantities and is computed as follows:

$$
A M I H=\frac{1}{T} \sum_{t=1}^{T} \frac{\left|R_{t}\right|}{V_{t}} \times 1,000,
$$

where $R_{t}$ is the stock return measured in logarithm on closing prices at date $t, V_{t}$ is the trading volume on date $t$ and $T$ is the number of trading days in the observation period. Lesmond, Ogden, and Trzcinka's (1999) measure $\left(L_{-} O_{-} T\right)$ is the ratio of zero-return days to the total number of trading days in the observation period. The assumption behind this measure is that no informed trading occurs when trading costs are high enough to offset trading gains, which leads to zero daily returns.

For the sub-sample of continuously traded stocks, we compute time-weighted average quoted spreads, 


$$
Q S=\frac{1}{\sum_{k=1}^{K} d_{k}}\left(\sum_{k=1}^{K} d_{k} \times \frac{a s k_{k}-b i d_{k}}{\operatorname{mid}_{k}}\right)
$$

average effective spreads,

$$
E S=\frac{1}{N}\left(\sum_{n=1}^{N} 2 \times \frac{\left|P_{n}-m i d_{n}\right|}{m i d_{n}}\right)
$$

and average realized spreads,

$$
R S=\frac{1}{N} \sum_{n=1}^{N} 2 \times \frac{P_{n}-\operatorname{mid}_{n+30 \mathrm{~min}}}{\operatorname{mid}_{n}} \times Q_{n},
$$

where $b i d_{k}, a s k_{k}, m i d_{k}$, and $d_{k}$, respectively, are the best bid quote, the best ask quote, the mid-quote, and the duration of the best quotes observed at the time of the $k^{\text {th }}$ quoted spread in the observation period; $K$ is the total number of quoted spreads observed for the stock in the observation period; $P_{n}$ is the transaction price for the $n^{\text {th }}$ transaction in the observation period; $\operatorname{mid}_{n}\left(\right.$ mid $\left._{n+30 \mathrm{~min}}\right)$ is the mid-quote prevailing at the time of (30 minutes after) the $n^{\text {th }}$ trade; $Q_{n}$ is the sign of the $n^{\text {th }}$ trade; and $N$ is the total number of trades in the period.

\subsection{Measures of information asymmetry}

Measures of information asymmetry are derived over the same six-month observation period as that chosen to measure liquidity. The magnitude of information asymmetry is estimated with three methodologies: the average 30-minute price impact denoted PIMP, the adverse-selection spread component of Lin, Sanger, and Booth (1995) denoted $\alpha_{l s b}$, the probability of informed trading (PIN) of Easley, Kiefer, O’Hara, and Paperman (1996), and the adjusted PIN of Duarte and Young (2009) denoted AdjPIN.

We conduct the decomposition of the effective spread in a realized spread and a price impact within a 30-minute interval following Bessembinder and Kaufman's (1997) approach. Price impacts at a 30-minute interval are calculated as follows: 


$$
P I M P=\frac{1}{N} \sum_{n=1}^{N} 2 \times \frac{\text { id }_{n+30 \min }-\operatorname{mid}_{n}}{\operatorname{mid}_{n}} \times Q_{n},
$$

where mid $_{n+30 \text { min }}$ is the mid-price quoted 30 minutes after the $n^{\text {th }}$ transaction of the period.

Lin, Sanger, and Booth's (LSB) adverse selection component $\alpha_{l s b}$ then is estimated for each stock as the sensitivity of mid-price revisions to trade sizes with the following regression model for each stock:

$$
\operatorname{mid}_{n+1}-\operatorname{mid}_{n}=\alpha_{l s b}\left(P_{n}-\operatorname{mid}_{n}\right)+e_{n+1}
$$

where mid $_{n+1}$ is the mid-quote prevailing immediately after the $n^{\text {th }}$ trade. All regressions are run with the Generalized Method of Moments (GMM).

Finally, we compute the PIN measure of Easley, Kiefer, O’Hara, and Paperman (1996), which is based on trade direction. The probability of observing $B$ buys and $S$ sells on a given day can be implemented as follows:

$$
\begin{aligned}
& L\left(\left(B_{t}, S_{t}\right)(\alpha, \delta, \mu, \varepsilon)\right)=(1-\alpha) \times e^{-2 \varepsilon} \frac{(\varepsilon)^{B_{t}}}{B_{t} !} \frac{(\varepsilon)^{S_{t}}}{S_{t} !} \\
& +\alpha \delta \times e^{-(2 \varepsilon+\mu)} \frac{(\varepsilon)^{B_{t}}}{B_{t} !} \frac{(\mu+\varepsilon)^{S_{t}}}{S_{t} !}+\alpha(1-\delta) \times e^{-(2 \varepsilon+\mu)} \frac{(\varepsilon)^{S_{t}}}{S_{t} !} \frac{(\mu+\varepsilon)^{B_{t}}}{B_{t} !}
\end{aligned}
$$

where $\alpha$ is the probability of an information event which is bad news with probability $\delta$ and good news with probability $1-\delta$. The arrival rate of informed trades is $\mu$. $\varepsilon$ is the rate of uninformed buy and sell trade arrivals. Over an observation period of $T$ days, the likelihood of observing $\left(B_{t}, S_{t}\right)_{t=1}^{T}$ buys and sells corresponds to the product of the daily likelihoods:

$$
L\left(\left(B_{t}, S_{t}\right)_{t=1}^{T} \mid(\alpha, \delta, \mu, \varepsilon)\right)=\prod_{t=1}^{T} L\left(\left(B_{t}, S_{t}\right)(\alpha, \delta, \mu, \varepsilon)\right)
$$

In order to estimate the $(\alpha, \delta, \mu, \varepsilon)$ parameters, we maximize the likelihood defined in equation (8), and the PIN is calculated as: 


$$
P I N=\frac{\alpha \mu}{\alpha \mu+2 \varepsilon}
$$

According to Duarte and Young (2009), the PIN may measure illiquidity as much as information asymmetry. In order to control for potential effects of illiquidity unrelated to information asymmetry, we also compute the Duarte and Young's (2009) adjusted PIN $(\operatorname{AdjPIN})$. which is calculated as:

$$
\operatorname{AdjPIN}=\frac{\alpha \mu}{\alpha \mu+2 \Delta \times\left(\alpha \theta^{\prime}+(1-\alpha) \theta\right)+2 \varepsilon}
$$

where $\theta$ measures the probability of an event conditional to the absence of private information, $\theta^{\prime}$ the probability of an event conditional to the arrival of private information. $\Delta$ measures the additional arrival rate of buys and sells.

\subsection{Measures of ownership structure}

Ownership structure data were extracted from IPO prospectuses. In order to estimate the ownership concentration, we identified all of the blockholders who possessed at least $5 \%$ of the firm's shares and computed their total holding in percentage (BLOCK). We also calculated the Herfindhal-Hirschmann index $(H E R F)$ by summing squared shareholdings of the five largest shareholders:

$$
H E R F=\sum_{i=1}^{5} s_{i}^{2}
$$

where $s_{i}$ is the part that belongs to the $i^{\text {th }}$ largest shareholder $(i=1, \ldots, 5)$.

\subsection{Measures of information production}

We first measured information production by the quantity of information disseminated about the firm in the press within the first six months following the IPO date. We extracted the number of citations of the IPO firm in the press from FACTIVA and took it in logarithm (\#FACT). Second, we considered the information produced by financial analysts. I/B/E/S data 
were collected for the same observation period to measure the intensity of analyst coverage by three metrics taken in logarithm: the number of brokerage firms covering the IPO (\#BR), the number of analysts $(\# A N)$, and the number of recommendations they issued (\#REC).

\section{Test design}

We started our empirical work by testing how initial underpricing was correlated with post-listing liquidity and information asymmetry. We then tested both the ownership dispersion hypothesis and the information production hypothesis by using a two-stage procedure. The first stage consisted of estimating the impact of initial underpricing on ownership concentration and on information. The second stage consisted of estimating how the values of ownership concentration and information production predicted in the first stage influenced post-listing liquidity. With regard to the information production hypothesis, the second stage also included a test on how the first-stage-predicted information variables correlated with the level of information asymmetry in the secondary market.

\subsection{The relation between initial underpricing and post-listing liquidity}

As a preliminary step, we measured to what extent post-listing liquidity and post-listing information asymmetry were positively correlated with initial underpricing by regressing low and high-frequency liquidity measures on the level of underpricing in the following way:

$$
\text { Liquidity or InfoAsym }=b_{0}+\sum_{i} b_{i} C V_{i}+b U_{1 w}+\widetilde{\varepsilon},
$$

where Liquidity was alternatively the average daily turnover (TURN), the Amihud illiquidity ratio $(A M I H)$, the zero-return ratio $\left(L_{-} O_{-} T\right)$, the average time-weighted quoted spread $(Q S)$, the average effective spread $(E S)$, or the average realized spread calculated at the 30 -minute horizon $(R S)$; InfoAsym was alternatively the average price impact calculated at the 30-minute horizon $(P I M P)$, the adverse selection cost component of the effective spread following Lin et 
al. (1995) $\left(\alpha_{l s b}\right)$, the probability of informed trading (PIN) estimated following Easley et al. (1996), and the adjusted PIN measure (AdjPIN) of Duarte and Young (2009); $\left\{C V_{i}\right\}_{i}$ is a set of control variables; $U_{1 w}$ is the initial adjusted return of the stock over the first week of trading; $\widetilde{\varepsilon}$ is the error term. In case of overpricing, $U_{1 w}$ is set to 0 .

For low-frequency liquidity measures, the set of control variables, $\left\{C V_{i}\right\}_{i}$, comprised the volatility of daily closing returns $(\sigma)$, firm size measured by the logarithm of the firm's market value at the IPO date $(\ln M V)$, price level measured by the average closing price during the liquidity observation period $(\ln P)$, ownership concentration measured by the post-IPO Herfindhal-Hirschmann index $(H E R F)$, a binary variable set to 1 if there was a lock-up agreement during the liquidity observation period ${ }^{7}$ and set to 0 otherwise (Lock-up), and a binary variable set to 1 if the IPO firm had signed a liquidity contract (LP_contract). We used the same control variables in the regressions of spreads except for the firm's initial market value $(\ln M V)$ which was replaced by the average daily trading volume taken in logarithm $(\ln V)$. In the regressions of information asymmetry variables, we controlled for volatility, market value, and price level as in the spread regressions. We also expected the information asymmetry to be greater if: (1) the managers had retained a greater shareholding after the listing; (2) the firm was introduced on a growth market; and (3) it belonged to the new technology sector. We therefore added as controls the shareholding of the manager after the IPO (MAN_postIPO), the market segment represented by dummy $N M$ equal to 1 when the

\footnotetext{
${ }^{7}$ Findings by Cao, Field, and Hanka (2004) suggest that lock-up agreements restrict liquidity. They find substantial improvements in trading volumes and depth at lock-up expirations although well-informed traders enter the market.
} 
IPO was undertaken in the growth market (Nouveau Marché or Alternext) and equal to 0 otherwise, and the NTIC dummy set to 1 for new-technologies IPO firms ( 0 for others).

However, this regression is not sufficient to show if the improvement of liquidity or the reduction of information asymmetry is due to either higher dispersed ownership or information production after the IPO. In order to test the two hypotheses, we used a two-step regression.

\subsection{Test of the ownership dispersion hypothesis}

In a first stage, we tested whether underpricing affected ownership structure by modeling our measures of ownership concentration (HERF and BLOCK) as a function of the underpricing level:

$$
\begin{aligned}
& \text { OwnConc }=d_{0}+d_{1} \ln M V+d_{2} \text { SaleRatio }+d_{3} F A M \\
& +d_{4} N M+d_{5} V C+d_{6} B B+d_{7} U_{1 w}+\widetilde{\varepsilon}_{\text {OwnConc }} .
\end{aligned}
$$

We controlled for market size $(\ln M V)$ and for the rate of newly-issued shares (SaleRatio), calculated as the number of new shares divided by the total number of shares outstanding after the IPO, because large IPO firms and IPOs with a greater proportion of newly-issued shares are expected to have more dispersed ownership. We also controlled for the percentage of shares retained by the manager's family after the IPO $(F A M)$ and the segment of listing (binary $N M$ ), as family-owned companies and growth firms usually have more concentrated shareholding structures. Finally, book-built IPOs as well as venture-backed IPOs may have a different ownership structures than others. We thus included two dummies to control for those effects: $V C$ which equals 1 for venture-backed IPOs ( 0 for others) and $B B$ which equals 1 for book-built IPOs (0 for others).

In the second stage, liquidity measures were regressed on ownership concentration measures as predicted in first-stage regressions (2): 


$$
\text { Liquidity }=h_{0}+\sum_{i} h_{i} C V_{i}+h_{p} \widehat{O} w n C o n c+h_{r} \hat{\varepsilon}_{\text {OwnConc }}+\widetilde{\eta} \text {. }
$$

The same control variables as in model (13), with the exception of the HERF concentration index, were used. ÔwnConc stands for the first-stage-predicted value of the concentration ownership index or alternatively the blockholders' shareholdings. The first-stage residual values of those variables ( $\hat{\varepsilon}_{\text {OwnConc }}$ ) also were considered as independent variables.

\subsection{Test of the information production hypothesis}

The test of the information production hypothesis was designed in the same way as that of the ownership dispersion hypothesis. In a first-stage, we regressed measures of information production on the underpricing measure $U_{1 w}$ :

$$
\text { InfoProd }=f_{0}+f_{1} \text { SaleRatio }+f_{2} H M+f_{3} N M+f_{4} R E P+f_{5} U_{1 w}+\widetilde{\varepsilon}_{\text {InfoProd }} .
$$

The measures of information production, generically denoted InfoProd, comprised press coverage measured by the number of citations in the press over the six-month period following the primary listing date (\#FACT), and measures of analyst coverage such as the number of brokers covering the IPO firm $(\# B R)$, the number of analysts $(\# A N)$, and the number of recommendations issued over the post-listing period (\#REC). These four variables are strongly determined by the size of the firm but controlling for $\ln M V$ in Regression (16) would be a source of colinearity in the second-stage regression. For this reason we chose to regress the previously-mentioned measures of information production, taken in logarithm, on $\ln M V$. We then used the residuals of these preliminary regressions as the dependent variables in Regression (16). IPOs with a higher sale ratio usually receive more coverage while growth IPOs receive less. IPO cyclicality is likely to impact the level of coverage. The reputation of the lead underwriter may also positively determine the probability of coverage, as shown by Cliff and Denis (2004). This led us to control for the sale ratio (SaleRatio), the listing market segment $(N M)$, the logarithm of the number of IPOs undertaken during the three months 
preceding the IPO $(H M)$, and the lead underwriter's reputation $(R E P)$ measured as its market share, following the approach of Megginson and Weiss (1991). This market share is calculated as the amount of funds in euro raised in the IPOs underwritten by the considered investment bank as a percentage of the total euro amount brought to market for all IPOs in the sample. If an IPO has more than one lead underwriter, the average of the underwriters' market shares is used as the measure of reputation. REP is taken in logarithm. ${ }^{8}$

At the second-stage level, all liquidity and information asymmetry measures were regressed on the predicted and residual values of the first-stage regression as follows:

$$
\text { Liquidity or InfoAsym }=j_{0}+\sum_{i} j_{i} C V_{i}+j_{p} \hat{\text { InfoProd }}+j_{r} \hat{\varepsilon}_{\text {InfoProd }}+\widetilde{v} \text {. }
$$

Control variables $C V_{i}$ are the same as those used in Regression (13). InfoProd is the firststage-predicted value of alternatively the number of press citations ( $\# \hat{F} A C T$ ), the number of brokers covering the firm $(\# \hat{B} R)$, the number of analysts (\# $\hat{A} N)$, and the number of recommendations issued on the stock (\#REC). $\hat{\varepsilon}_{\text {InfoProd }}$ denotes the first-stage residual of each of those four variables.

\section{Results}

Table 1 presents general statistics for the sample on issue characteristics, initial underpricing, liquidity, risk, ownership structure, and analyst coverage intensity. Ownership statistics show that after the IPO, blockholders own a great proportion of most firms' shares. On average, around $67 \%$ of shares are retained by shareholders who own more than $5 \%$ of

\footnotetext{
${ }^{8}$ We also estimated the market share of an underwriter by the percentage of offerings it underwrote in the sample. Results were unchanged.
} 
shares after the IPO, and more than $40 \%$ of the shares are retained by the managers after the IPO. Furthermore, institutional holdings are substantial with an average share that almost reaches $15 \%$. Average liquidity levels are those typically observed for middle capitalization stocks. Regarding analyst coverage, the average number of brokers and the average number of analysts per IPO both range between one and two, and the average number of recommendations they issue within the six months following the initial offering exceeds two, with large cross-section discrepancies.

\section{Table 1 about here}

The relations between initial underpricing, liquidity, ownership dispersion, and information production then are investigated through the multivariate analysis described in Section 5. Table 2 presents the results for the relation between initial underpricing and aftermarket liquidity on the one hand, and the relation between initial underpricing and information asymmetry on the other (Regressions 13). In accordance with most previous studies, the estimations show that post-listing liquidity positively correlates with initial underpricing. The statistical significance of the underpricing variable coefficients reaches $1 \%$ in all regressions of liquidity variables with the exception of realized spreads in which the significance is still $5 \%$. This liquidity effect is partially supported by an information asymmetry reduction effect. Information asymmetry significantly decreases with initial underpricing at the $1 \%$ level when measured by price impact $(P I M P)$, at the $10 \%$ level when measured by $\alpha_{l s b}$ and the PIN, and at the 5\% level when measured by the adjusted PIN $(\operatorname{Adj} P I N)$.

The influence of initial underpricing on liquidity and information asymmetry was controlled for traditional effects such as volatility, size, trading volume and price level. Regarding other control variables, Table 2 proves clear evidence that liquidity decreases with ownership concentration. Liquidity is not clearly affected by the existence of a lock-up 
agreement or a liquidity provision contract. Asymmetric information does not relate to either the managers' shareholding or the new-technologies dummy, but it is stronger for IPOs undertaken on the Nouveau Marché and its successor, Alternext, the French growth markets.

\section{Table 2 about here}

Table 3 presents the estimations for the second-stage regressions of shareholding structure variables on underpricing. These results indicate that ownership dispersion is unrelated to initial underpricing, so that the liquidity effect cannot be viewed as formed through the mediation of ownership structure, in contrast with the findings of Pham et al. (2003), based on a sample from Australia. Similar to Hill (2006) for the UK, we reject hypothesis $\mathrm{H} 1 \mathrm{a},{ }^{9}$ and rejecting $\mathrm{H} 1 \mathrm{a}$ makes testing $\mathrm{H} 1 \mathrm{~b}$ unnecessary. Regarding the control variables in Regression (14), Table 3 shows that venture-backed IPOs, book-built IPOs, and IPOs with more shares sold in the offering have a more dispersed ownership after the IPO. Conversely, family ownership and firm size favor ownership concentration after the IPO.

\section{Table 3 about here}

The estimates obtained from regressing information production measures on IPO underpricing are shown in Table 4. While underpricing has no significant impact on press coverage, it stimulates analyst coverage very significantly. We thus fail to reject $\mathrm{H} 2 \mathrm{a}$ for public analyst-produced information. We can also note that analyst coverage increases with the percentage of shares sold in the IPO. The results for binary variable $N M$ show that

\footnotetext{
${ }^{9}$ As no significant relation is found between ownership concentration and underpricing, we cannot support the opposite theory of Stoughton and Zechner (1998), who suggest that IPO firms underprice their stocks at issuance to create a more concentrated ownership structure.
} 
financial analysts pay less attention to IPOs conducted on growth markets. Results in Table 4 also reveal that information production does not intensify during hot market periods.

In the second stage, liquidity positively correlates with the analyst coverage intensity predicted by underpricing (cf. Table 5). This finding holds at the $1 \%$ significance threshold according to all liquidity metrics except the Amihud ratio. This provides support for $\mathrm{H} 2 \mathrm{~b}$. With respect to control variables, the traditional effects of volatility, size, and price level on liquidity are found. Unexpectedly, IPO stocks with a lock-up period appear to be more liquid and those with a liquidity provision contract are not.

Finally, all information asymmetry measures are significantly reduced by first-stagepredicted underpricing (cf. Table 6), which supports H2c. The statistical significance of this relation is greater when information asymmetry is measured by price impact metrics (1\%level significance for PIMP and $\alpha_{l s b}$ ) than when it is measured by probabilities of informed trading (10\% or 5\%-level significance for PIN and AdjPIN). Marginally, the coefficients of control variables show that the presence of informed traders is greater in growth markets. Asymmetric information costs increase with volatility but the proportion of informed traders in the market does not. Information asymmetry is inversely linked to firm size if we consider asymmetric information costs but the probability of informed trading is positively correlated with firm size.

\section{Tables 4, 5, and 6 about here}

In summary, our findings do not support the ownership dispersion hypothesis (rejection of H1a and H1b) but strongly support the information production hypothesis (no rejection of $\mathrm{H} 2 \mathrm{a}, \mathrm{H} 2 \mathrm{~b}$, and $\mathrm{H} 2 \mathrm{c}$ ), the relevant information for liquidity being that produced by analysts and not press coverage. 


\section{Robustness checks}

This section is dedicated to checking whether our results are biased by endogeneity or driven by specific groups of IPOs or outliers.

\subsection{Endogeneity}

It could be argued that our results suffer from a selectivity bias resulting from underpricing being caused by factors determining the liquidity of the stock after the IPO. For example, if the largest IPOs are the most underpriced, they will also have the best liquidity and the lowest adverse selection costs in the post-listing market, not because they were initially underpriced, but due to their market size. In order to address this potential bias, we use a Heckman correction by adding a preliminary stage in which the probability of underpricing is estimated in a logistic regression. In this preliminary stage, the probability for an issue to be underpriced, denoted $P\left(U_{1 w}>0\right)$, is modeled as a function of the pre-IPO managers' holdings $\left(M A N \_\right.$preIPO), a binary equal to 1 for VC-backed IPOs $(V C)$, the percentage of shares sold in the IPO (SaleRatio), the IPO cycle measured by the number of offerings in the preceding three months $(H M)$, underwriter quality measured by IPO market share $(R E P)$, and a dummy equal to 1 for IPOs with a liquidity provider contract. ${ }^{10}$

Regarding the impact of venture capitalists $(V C)$ on IPO underpricing, there are two opposite theories. The certification hypothesis states that venture capitalists help certify the true value of the firm (Megginson and Weiss, 1991; Barry, Muscarella, Peavy, and

\footnotetext{
${ }^{10}$ Others factors comprising earnings per share, the $\mathrm{P} / \mathrm{E}$ ratio, the book-to-market ratio, the age of the firm, the debt leverage, the return on assets, the IPO size measured as the number of shares on sale in the IPO multiplied by the subscription price, the post-listing market value, and the price level, were inserted into the model, but none of them were proved to influence the probability of underpricing.
} 
Vetsuypens, 1990). This certification effect induces a reduction in underpricing when the firm goes public. In contrast with this theory, Gompers (1993) develops a theoretical model in which young venture capitalists are ready to support additional costs in order to introduce firms, so that VC-backed IPOs should be more underpriced. This is supported by the findings of Gompers (1996) and Lee and Wahal (2004). Regarding underwriter reputation, Carter and Manaster (1990) found it to be negatively correlated with underpricing for U.S. IPOs in the 1970s and 1980s but this correlation became positive in the 1990s according to Beatty and Welch (1996).

Table 7 reports the estimates of the logistic regression. They support the certification hypothesis which predicts a reduction in underpricing when the IPO is venture-backed. Also, higher underpricing is observed when the firm has signed a liquidity contract. Hot market periods, the ratio of shares sold in the IPO, the managers' shareholdings prior to the IPO, and underwriter quality have no significant influence on initial underpricing.

\section{Table 7 about here}

Following the preliminary stage, regressions (13), (14), (16), and (17) were reestimated, replacing the underpricing variable by the product of the underpricing probability as estimated from the logistic regression and the realized underpricing $U_{l w}$. For overpriced IPOs, this variable was set to zero. The results obtained from this three-stage procedure are very similar to those of Section 6 and conclusions remain unchanged. With an R-square below $10 \%$, the first-stage logistic regression poorly explains the cross-section of underpricing and we consider that the results of Section 6 are not subject to endogeneity.

\subsection{Analysis by sub-groups}

The first issue we address here is whether our findings are created by a dichotomy between underpriced IPOs and others, or whether the level of underpricing is important. This 
question is answered by running the double-stage regressions on the sub-sample of underpriced IPOs (231 firms among which 114 have continuously traded shares). We obtain the same conclusions as for the whole sample, with the statistical significance of the impact of underpricing-predicted coverage on the probability of informed trading increasing to $5 \%$ for both the PIN and the AdjPIN measures. This leads us to consider that not only the occurrence of underpricing but also the magnitude of initial returns influences post-listing liquidity through additional information production.

Second, we focus on the book-building mechanism. It is often argued that the discretionary power of underwriters characterizing the share allocation in book-built offerings is used to shape ownership structure, either by allocating to buy-and-hold investors (Cornelli and Goldreich, 2001; Jenkinson and Jones, 2004), or by favoring small or large shareholders (Brennan and Franks, 1997; Stoughton and Zechner, 1998). Further, Degeorge, Derrien, and Womack (2007) find that underwriters use discretion to allocate more shares to banks that will provide positive analyst coverage. Such practices might strengthen or weaken the relations between underpricing, ownership concentration, analyst coverage, and liquidity for book-built IPOs. We therefore repeat the tests over the sub-sample of book-built offers which comprises 247 IPO stocks out of which 147 are continuously traded. All findings are similar with the exception that: (1) the statistical significance of the negative correlation between underpricing and the Herfindhal-Hirschmann concentration index of post-listing ownership increases to $10 \%$, and (2) the impact of the coverage generated by underpricing on information asymmetry, while still significant for the LSB measure and price impact, fails to be significant for informed trading probabilities.

Third, we consider the sub-group of IPOs for which there is a primary offer, as ownership and coverage issues might be more relevant for IPOs issuing new shares. This sub- 
group counts 261 stocks, with 135 being continuously traded. The findings are exactly the same as those for the book-built sub-sample.

Fourth, underwriter quality might change the triple relation linking underpricing, information production, and liquidity, as on the one hand, high-quality underwriters are more inclined to cover their IPOs (Cliff and Denis, 2004), and on the other, IPO stocks underwritten by more reputed banks have been found to be more liquid (Popescu and $\mathrm{Xu}$, 2011) independent of their initial returns. To test this hypothesis, we reduced the sample to IPOs underwritten by more reputed banks, defined as those having a greater market share $(R E P)$ than the median market share. This criterion produced a group of 247 IPOs (130 being continuously traded), from which we drew the same conclusions as those drawn from the complete sample, with the difference that the impact of underpricing-induced coverage on informed trading probabilities is slightly more significant.

Last, stock markets experienced a strong liquidity dry up at the end of our observation period when the subprime crisis happened. To check if our findings are driven by outliers in the illiquid period, we shortened the observation period and dropped from the sample the IPOs undertaken after 30 June 2007. Conclusions remain unchanged although, due to sample size reduction, we lose the statistical significance of the coverage variable coefficients for the PIN and AdjPIN measures in the regressions of Table 6.

\section{Conclusion}

Using a sample of Euronext IPOs issued between 1995 and 2008, we find that more underpriced IPO stocks are more intensively traded and have lower liquidity costs in the postlisting period. Further, adverse selection costs and informed trading are lower for more underpriced IPO stocks, which suggests that more public information is produced for these stocks. In contrast to Booth and Chua's theory, we fail to prove that those effects result from a 
more diffuse ownership obtained by underpricing the issue. Instead, we find that they are the result of the information momentum modeled by Chemmanur (1993) and Aggarwal et al. (2002), or, in other words, of analyst coverage attracted by the good performance of underpriced-IPO stocks in the immediate aftermarket. The increased analyst coverage generated about a firm by underpricing its IPO contributes to reducing informed trading and adverse selection costs. While the impact on adverse selection costs is very significant and robust, the impact on the proportion of informed traders has a weaker statistical significance and is not robust to all sample distortions.

Our results enlighten the importance of analysts' activity around IPOs not only for aftermarket prices but also for the liquidity of the secondary market in the months following the IPO. Whether this liquidity effect produced by underpricing-purchased analyst coverage persists in the long run is still an open question. Another question of interest for future research is whether this liquidity effect impacts long-term performances and the market conditions of future seasoned equity offerings. 


\section{References}

Aggarwal R. K., L. Krigman, and K. L. Womack, 2002, "Strategic IPO Underpricing, Information Momentum, and Lockup Expiration Selling”, Journal of Financial Economics, 66(1), 105-137.

Amihud Y., 2002, "Illiquidity and Stock Returns: Cross-section and Time-series Effects", Journal of Financial Markets, 5(1), 31-56.

Amihud Y. and H. Mendelson, 1986, “Asset Pricing and the Bid-Ask Spread”, Journal of Financial Economics, 17(2), 223-249.

Barry C. B., C. J. Muscarella, J. W. Peavy and M. R. Vetsuypens, 1990, “The role of venture capital in the creation of public companies: Evidence from the going-public process", Journal of Financial Economics, 27(2), 447-471.

Beatty R. P. and I. Welch, 1996, "Issuer Expenses and Legal Liability in Initial Public Offerings", Journal of Law and Economics, 39(2), 545-603.

Bessembinder H. and H. M. Kaufman, 1997, “A Comparison of Trade Execution Costs for NYSE and NASDAQ-Listed Stocks", Journal of Financial and Quantitative Analysis, 32(3), 287-310.

Booth J. R. and L. Chua, 1996, “Ownership Dispersion, Costly Information and IPO Underpricing”, Journal of Financial Economics, 41(2), 291-310.

Bradley D. J., B. D. Jordan, and J. R. Ritter, 2003, “The Quiet Period Goes out with a Bang”, Journal of Finance, 58(1), 1-36.

Brennan M. J. and J. Franks, 1997, “Underpricing, Ownership and Control in Initial Public Offerings of Equity Securities in the UK”, Journal of Financial Economics, 45(3), 391413. 
Brennan M. J. and A. Subrahmanyam, 1996, "Market Microstructure and Asset Pricing: On the Compensation for Illiquidity in Stock Returns", Journal of Financial Economics, $41(3), 441-464$.

Brockman P., D. Y. Chung, and X. Yan, 2009, "Block Ownership, Trading Activity, and Market Liquidity”, Journal of Financial and Quantitative Analysis, 44(6), 1403-1426.

Butler A. W., G. Grullon, and J. P. Weston, 2005, "Stock Market Liquidity and the Cost of Raising Capital“", Journal of Financial and Quantitative Analysis, 40(2), 331-348.

Cao C., L. C. Field, and G. Hanka, 2004, "Does Insider Trading Impair Market Liquidity? Evidence from IPO Lockup Expirations", Journal of Financial and Quantitative Analysis, 39(1), 25-46.

Chemmanur T. J., 1993, “The Pricing of Initial Public Offerings: A Dynamic Model With Information Production”, Journal of Finance, 48(1), 285-304.

Cliff M. and D. Denis, 2004, "Do Initial Public Offering Firms Purchase Analyst Coverage with Underpricing?”, Journal of Finance, 59(6), 2871-2901.

Cornelli F. and D. Goldreich, 2001, "Book-Building and Strategic Allocations", Journal of Finance, 56(6), 2337-2370.

Corwin S. A., J. H. Harris, and M. L. Lipson, 2004, “The Development of Secondary Market Liquidity for NYSE-listed IPOs”, Journal of Finance, 59(5), 2339-2373.

Degeorge F., F. Derrien, and K. L. Womack, 2007, “Analyst Hype in IPOs: Explining the Popularity of Bookbuilding”, Review of Financial Studies, 20(4), 1021-1058.

Duarte J. And L. Young, 2009, "Why is PIN priced?”, Journal of Financial Economics, 91(2), 119-138. 
Easley D., N. M. Kiefer, M. O’Hara, and J. Paperman, 1996, “Liquidity, Information, and Infrequently Traded Stocks", Journal of Finance, 51(4), 1405-1436.

Ellul A. and M. Pagano, 2006, "IPO Underpricing and After-Market Liquidity", Review of Financial Studies, 19(2), 381-421.

Francis B. B., I. Hasan, J. R. Lothian, and X. Sun, 2010, "The Signaling Hypothesis Revisited: Evidence from Foreign IPOs", Journal of Financial and Quantitative Analysis, 45(1), 81-106,

Gajewski J.-F. and C. Gresse, 2006, "A Survey of the European IPO Market”, ECMI Research Reports, No. 2, European Capital Markets Institute, August.

Ginglinger E. and J. Hamon, 2007, “Ownership control and market liquidity”, Working paper Université Paris-Dauphine

Gompers P. A., 1993, "The theory, structure and performance of venture capital", Unpublished PhD thesis, Harvard University, Cambridge, MA.

Gompers P. A., 1996, "Grandstanding in the venture capital industry", Journal of Financial Economics, 42(1), 133-156.

Hanley K. W., 1993, "Underpricing of Initial Public Offerings and the Partial Adjustment Phenomenon", Journal of Financial Economics, 34(2), 231-250.

Hahn T. and J. A. Ligon, 2006, "Liquidity and Initial Public Offering Underpricing", Working paper, University of Idaho and University of Alabama.

Heflin F. and K. W. Shaw, 2000, "Blockholder Ownership and Market Liquidity", Journal of Financial and Quantitative Analysis, 35(4), 621-633.

Hill P., 2006, “Ownership Structure and IPO Underpricing”, Journal of Business Finance and Accounting, 33(1-2), 102-126. 
Ibbotson R. G. and J. R. Ritter, 1995, "Initial Public Offerings", in: Jarrow R. A., V. Maksimovic and W. T. Ziemba (eds.), Handbooks in Operations Research and Management Science: Finance, 9, North-Holland, Amsterdam, 993-1016.

Jenkinson T. and H. Jones, 2004, "Bids and Allocation in European IPO Book-Building", Journal of Finance, 59(5), 2309-2339.

Lee P. M., and S. Wahal, 2004, "Grandstanding, certification and the underpricing of venture capital backed IPOs”, Journal of Financial Economics, 73(2), 375-407.

Lesmond D. A., J. P. Ogden, and C. A. Trzcinka, 1999, “A New Estimate of Transaction Costs”, Review of Financial Studies, 12(5), 1113-1141.

Li M., T. H. McInish, and U. Wongchoti, 2005, "Asymmetric Information in the IPO Aftermarket”, The Financial Review, 40(2), 131-153.

Li M., S. X. Zheng, and M. V. Melancon, 2005, “Underpricing, Share Retention, and the IPO Aftermarket Liquidity", International Journal of Managerial Finance, 1(2), 76-94.

Lin, J.-C., G. C. Sanger, and G. G. Booth, 1995, "Trade Size and Components of the Bid-ask Spread", Review of Financial Studies, 8(4), 1153-1183.

Maug E., 1998, "Large Shareholders as Monitors: Is There a Trade-off between Liquidity and Control?", Journal of Finance, 53(1), 65-98.

Megginson W. L., and K. A. Weiss, 1991, "Venture Capitalist Certification in Initial Public Offerings", Journal of Finance, 46 (3), 879-903.

Michaely R. and W. H. Shaw, 1994, "The Pricing of Initial Public Offerings: Tests of the Adverse-Selection and Signalling Theories", Review of Financial Studies, 7(2), 279319. 
Miller R. E. and F. K. Reilly, 1987, “An Examination of Mispricing, Returns and Uncertainty for Initial Public Offerings", Financial Management, 16(2), 33-38.

Pham P. K., P. S. Kalev, and A. B. Steen, 2003, “Underpricing, Stock Allocation, Ownership Structure and Post-Listing Liquidity of Newly Listed Firms", Journal of Banking and Finance, 27(5), 919-947.

Popescu M. and Z. Xu, 2011, "Co-managers, Information, and the Secondary Market Liquidity of Initial Public Offerings”, Financial Management, 40(1), 199-218

Rajan R. and H. Servaes, 1997, “Analyst Following of Initial Public Offerings”, Journal of Finance, 52 (2), 507-529.

Reese W. A., 1998, “IPO Underpricing, Trading Volume, and Investor Interest”, Working paper, Tulane University.

Ritter J. and I. Welch, 2002, “A Review of IPO Activity, Pricing, and Allocations”, Journal of Finance, 57(4), 1795-1828.

Schultz P. H. and M. A. Zaman, 1994, “Aftermarket Support and Underpricing of Initial Public Offerings", Journal of Financial Economics, 35(2), 199-219.

Stoughton N. M. and J. Zechner, 1998, "IPO-mechanisms, Monitoring and Ownership Structure", Journal of Financial Economics, 49(1), 45-77.

Zheng S. X. and M. Li, 2008, "Underpricing, Ownership Dispersion, and Aftermarket Liquidity on IPO Stocks", Journal of Empirical Finance, 15(3), 436-454. 
Table 1. Descriptive statistics on sample firms

\begin{tabular}{|c|c|c|c|c|c|c|}
\hline Variable & \# Obs & Mean & Median & Min & Max & Standard-deviation \\
\hline$A G E$ & 326 & 13.33 & 9 & 0.25 & 139 & 14.75 \\
\hline$P_{0}$ & 326 & 20.01 & 17.5 & 2 & 113 & 12.22 \\
\hline IPO_size & 326 & $16,473,742$ & $16,224,447$ & $13,841,845$ & $22,547,763$ & $1,337,213$ \\
\hline$M V$ & 326 & 444.61 & 50.73 & 3.81 & 58037.37 & 3493.40 \\
\hline Sharesonsale & 326 & $3,654,526$ & 729,356 & 83,482 & $187,869,028$ & $15,632,285$ \\
\hline SaleRatio & 326 & 0.2550 & 0.2413 & 0.0360 & 1.4525 & 0.1366 \\
\hline$U_{I}$ & 326 & $2.80 \%$ & $0.05 \%$ & $-27.61 \%$ & $132.72 \%$ & $13.25 \%$ \\
\hline$U_{l w}$ & 326 & $15.63 \%$ & $6.13 \%$ & $-28.77 \%$ & $260.33 \%$ & $31.40 \%$ \\
\hline$U_{I m}$ & 326 & $20.06 \%$ & $5.22 \%$ & $-32.35 \%$ & $438.09 \%$ & $50.70 \%$ \\
\hline$V$ & 326 & 817,243 & 62,824 & 38 & $104,282,174$ & $6,213,134$ \\
\hline$T U R N$ & 326 & $0.1349 \%$ & $0.1002 \%$ & $0.0001 \%$ & $1.4015 \%$ & $0.1308 \%$ \\
\hline$\sigma$ & 326 & $3.1639 \%$ & $2.7242 \%$ & $0.7644 \%$ & $11.0731 \%$ & $1.6448 \%$ \\
\hline$Q S$ & 154 & $1.6845 \%$ & $1.3543 \%$ & $0.0767 \%$ & $7.3243 \%$ & $1.1679 \%$ \\
\hline$E S$ & 154 & $1.3609 \%$ & $1.1239 \%$ & $0.0759 \%$ & $6.7158 \%$ & $0.9074 \%$ \\
\hline$R S$ & 153 & $0.4539 \%$ & $0.3601 \%$ & $0.0308 \%$ & $2.6925 \%$ & $0.3575 \%$ \\
\hline$B L O C K \_$preIPO & 326 & 0.8948 & 0.9292 & 0.3700 & 1 & 0.1171 \\
\hline BLOCK_postIPO & 326 & 0.6716 & 0.6853 & 0 & 0.9863 & 0.1404 \\
\hline INST_preIPO & 326 & 0.2091 & 0.0912 & 0 & 1 & 0.2729 \\
\hline INST_postIPO & 326 & 0.1472 & 0.0556 & 0 & 0.9035 & 0.2052 \\
\hline$M A N \_$preIPO & 326 & 0.5075 & 0.5236 & 0 & 1 & 0.3616 \\
\hline$M A N \_$postIPO & 326 & 0.4051 & 0.4282 & 0 & 0.9706 & 0.2979 \\
\hline FAM_preIPO & 326 & 0.2860 & 0 & 0 & 1 & 0.3789 \\
\hline$F A M \_$postIPO & 326 & 0.2286 & 0 & 0 & 0.9994 & 0.3092 \\
\hline HERF_preIPO & 326 & 0.4377 & 0.3730 & 0.0001 & 1 & 0.2775 \\
\hline$H E R F \_$postIPO & 326 & 0.2702 & 0.2300 & 0.0016 & 0.8234 & 0.1862 \\
\hline$\# A N$ & 326 & 1.79 & 1 & 0 & 23 & 3.31 \\
\hline$\# B R$ & 326 & 1.78 & 1 & 0 & 23 & 3.22 \\
\hline$\# R E C$ & 326 & 2.31 & 1 & 0 & 39 & 4.79 \\
\hline
\end{tabular}

$A G E$ is the age of the firm at the time of the IPO. $P_{0}$ is the IPO price. IPO_size corresponds to the issue size equal to the number of shares on sale times the IPO price. $M V$ is the market value of the firm. Sharesonsale is the number of shares sold in the IPO. SaleRatio is the ratio of shares sold in the IPO divided by the number of outstanding shares following the IPO. For each stock of the sample, IPO underpricing $U_{1}, U_{1 w}$ and $U_{1 m}$ are measured as the adjusted return observed, respectively, over the first day, the first week and the first month. All trading measures are estimated over the six months following the IPO date. $V$ is the average trading volume in $€$ over this post-listing period. TURN is the average daily turnover, which is the average daily volume in percentage of the number of shares sold in the IPO. $\sigma$ is the closing return volatility. We compute timeweighted average quoted, effective and realized spreads (QS, ES and RS). BLOCK is the percentage of shares controlled by the blockholders. INST is the percentage of shares controlled by institutional investors. $M A N$ is the percentage of shares retained by the managers. FAM is the percentage of shares controlled by the family. HERF is the Herfindhal-Hirschmann index of ownership concentration. \#AN, \#BR and \# REC are, respectively, the number of analysts, brokers and recommendations during the post-listing period. 


\section{Table 2. Impact of initial underpricing on liquidity and information asymmetry in the secondary market}

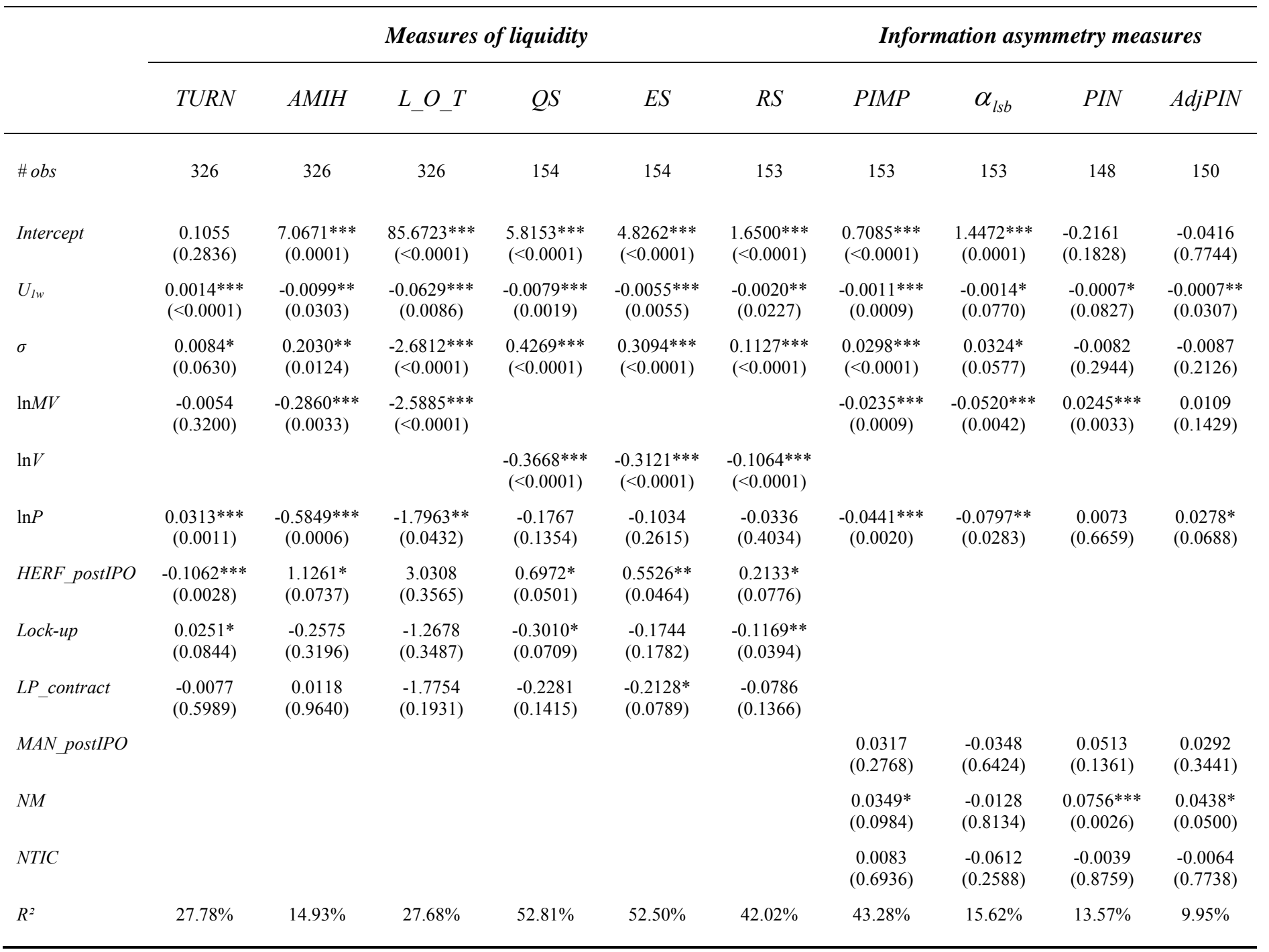

For each stock of the sample, IPO underpricing is measured as the adjusted return $(U)$ observed over the first five trading days for underpriced issues and is set to 0 for others. Liquidity and information asymmetry measures are estimated over a six-month period following the IPO date. The average daily turnover $(T U R N)$, that is the average daily volume in percentage of the number of shares sold in the IPO, the Amihud illiquidity ratio (AMIH) and the Lesmond, Ogden, and Trczinka's zero-return ratio $\left(L_{-} O_{-} T\right)$ are calculated for every stock. Time-weighted average quoted spreads $(Q S)$, average effective spreads $(E S)$ and average realized spreads $(R S)$ are computed for continuously traded stocks. $\alpha_{l s b}$, PIMP, PIN, and $A d j P I N$ denote the Lin, Sanger, and Booth's alpha coefficient, the average 30-minute price impact, the PIN measure and the adjusted PIN measure respectively. They are estimated for continuously traded stocks only. Control variables comprise the closing return volatility $(\sigma)$, the market value in logarithm $(\ln M V)$, the logarithm of the average trading volume in $€(\ln V)$, the average post-listing closing price in logarithm $(\ln P)$, the Herfindhal-Hirschmann index of ownership concentration measured after the IPO (HERF postIPO), a binary variable equal to 1 if there is a lock-up period (Lock-up), a binary variable equal to 1 if there is a liquidity provider contract ( $L P$ contract), the managers' holdings after the IPO (MAN_postIPO), a binary variable equal to 1 for New Market or Alternext issues $(N M)$, a binary variable equal to 1 for new technologies firms $(N T I C)$. ***,**,* indicate that the coefficient is significantly positive or negative, respectively, at the 1, 5, and 10\% level; $p$-values are reported in brackets. 
Table 3. Impact of initial underpricing on ownership concentration

\begin{tabular}{|c|c|c|}
\hline & HERF_postIPO & $B L O C K \_$postIPO \\
\hline Intercept & $\begin{array}{c}0.1066 \\
(0.4305)\end{array}$ & $\begin{array}{c}0.7248 * * * \\
(<0.0001)\end{array}$ \\
\hline $\ln M V$ & $\begin{array}{c}0.0211 * * * \\
(0.0047)\end{array}$ & $\begin{array}{c}0.0081 \\
(0.1217)\end{array}$ \\
\hline SaleRatio & $\begin{array}{c}-0.2880 * * * \\
(<0.0001)\end{array}$ & $\begin{array}{c}-0.4423 * * * \\
(<0.0001)\end{array}$ \\
\hline$F A M \_$postIPO & $\begin{array}{l}0.0565 * \\
(0.0608)\end{array}$ & $\begin{array}{l}0.0404 * \\
(0.0579)\end{array}$ \\
\hline$N M$ & $\begin{array}{l}-0.0325 \\
(0.1150)\end{array}$ & $\begin{array}{c}-0.0263 * \\
(0.0708)\end{array}$ \\
\hline$V C$ & $\begin{array}{c}-0.1352 * * * \\
(<0.0001)\end{array}$ & $\begin{array}{c}-0.0680 * * * \\
(<0.0001)\end{array}$ \\
\hline$B B$ & $\begin{array}{c}-0.0766 * * * \\
(0.0081)\end{array}$ & $\begin{array}{c}-0.0579 * * * \\
(0.0046)\end{array}$ \\
\hline$U_{l w}$ & $\begin{array}{l}-0.0003 \\
(0.2551)\end{array}$ & $\begin{array}{c}0.0000 \\
(0.8723)\end{array}$ \\
\hline \#obs. & 326 & 326 \\
\hline$R^{2}$ & $33.27 \%$ & $41.42 \%$ \\
\hline \multicolumn{3}{|c|}{$\begin{array}{l}\text { Dependant variables are the Herfindhal-Hirschmann index of ownership concentration measured after the IPO } \\
\left(H E R F \_ \text {postIPO) and the percentage of shares controlled by the blockholders after the IPO }\left(B L O C K \_ \text {postIPO). IPO }\right.\right. \\
\text { underpricing is measured as the adjusted return }(U) \text { observed over the first five trading days for underpriced issues and is set to } \\
0 \text { for others. Control variables comprise the market value in logarithm }(\ln M V) \text {, the ratio of shares sold in the IPO divided by the } \\
\text { number of outstanding shares following the IPO (SaleRatio), the percentage of shares controlled by the family after the IPO } \\
\left(F A M \_ \text {postIPO), a binary variable equal to } 1 \text { for New Market or Alternext issues }(N M) \text {, a binary variable equal to } 1 \text { if the firm }\right. \\
\text { is VC-backed }(V C) \text { and a binary variable equal to } 1 \text { for book-buildings }(B B) \text {. ***,*** indicate that the coefficient is } \\
\text { significantly positive or negative, respectively, at the } 1,5 \text {, and } 10 \% \text { level; } p \text {-values are reported in brackets. }\end{array}$} \\
\hline
\end{tabular}


Table 4. Impact of initial underpricing on public information production

\begin{tabular}{lcccc}
\hline & $\#$ REC & $\# B R$ & $\# A N$ & $\# F A C T$ \\
\hline Intercept & -0.1735 & -0.0524 & -0.1120 & 0.0100 \\
& $(0.2788)$ & $(0.7055)$ & $(0.4151)$ & $(0.9715)$ \\
SaleRatio & $0.7759^{* * *}$ & $0.6254^{* * *}$ & $0.7145^{* * *}$ & $1.1246^{* *}$ \\
& $(0.0022)$ & $(0.0044)$ & $(0.0010)$ & $(0.0111)$ \\
NM & $-0.1654^{* *}$ & $-0.2046^{* * *}$ & $-0.1784^{* * *}$ & 0.1067 \\
& $(0.0211)$ & $(0.0010)$ & $(0.0038)$ & $(0.3934)$ \\
$H M$ & 0.0164 & -0.0071 & -0.0052 & $-0.1293 *$ \\
& $(0.6905)$ & $(0.8413)$ & $(0.8822)$ & $(0.0734)$ \\
REP & 0.0169 & 0.0155 & 0.0135 & 0.0143 \\
& $(0.4562)$ & $(0.4302)$ & $(0.4868)$ & $(0.7179)$ \\
$U_{\text {lw }}$ & $0.0057^{* * *}$ & $0.0047 * * *$ & $0.0053^{* * *}$ & 0.0007 \\
& $(<0.0001)$ & $(<0.0001)$ & $(<0.0001)$ & $(0.7063)$ \\
\# obs. & 326 & 326 & 326 & 326 \\
$R^{2}$ & $10.47 \%$ & $10.78 \%$ & $12.26 \%$ & $3.52 \%$ \\
\hline
\end{tabular}

This table displays the estimations of public information production measures on underpricing. \#AN, \# BR and \# REC are, respectively, the number of analysts, brokers and recommendations during the post-listing period (in logarithm). FACT is the number of citations in the press during the six months following the IPO. IPO underpricing is measured as the adjusted return $(U)$ observed over the first five trading days for underpriced issues and is set to 0 for others. Control variables comprise the ratio of shares sold in the IPO divided by the number of outstanding shares following the IPO (Saleratio), a binary variable equal to 1 for New Market or Alternext issues $(N M)$, the number of IPOs over the preceding 3 months $(H M)$ in logarithm and $R E P$ is the market share of all lead underwriters for an IPO (in logarithm). ***,**** indicate that the coefficient is significantly positive or negative, respectively, at the 1,5 , and $10 \%$ level; $p$-values are reported in brackets. 
Table 5. Impact of predicted analyst coverage on liquidity

\begin{tabular}{|c|c|c|c|c|c|c|c|c|c|c|c|c|c|}
\hline & Intercept & $\sigma$ & $\ln M V$ & $\ln V$ & $\ln P$ & HERF_postIPO & Lock-up & LP_contract & $\# \hat{A N}$ & $\# \hat{B R}$ & $\# \hat{R} E C$ & $\# O b s$ & $R^{2}$ \\
\hline$T U R N$ & $\begin{array}{c}0.2728 * * * \\
(0.0017)\end{array}$ & $\begin{array}{c}0.0103 * * * \\
(0.0048)\end{array}$ & $\begin{array}{c}-0.0115^{* *} \\
(0.0146)\end{array}$ & & $\begin{array}{c}0.0091 \\
(0.2745)\end{array}$ & $\begin{array}{c}-0.0533 * \\
(0.0843)\end{array}$ & $\begin{array}{c}0.0516 * * * \\
(0.0001)\end{array}$ & $\begin{array}{l}-0.0117 \\
(0.3555)\end{array}$ & $\begin{array}{l}0.3913 * * * \\
(<0.0001)\end{array}$ & & & 326 & $46.17 \%$ \\
\hline$T U R N$ & $\begin{array}{c}0.3144 * * * \\
(0.0005)\end{array}$ & $\begin{array}{c}0.0121^{* * * *} \\
(0.0012)\end{array}$ & $\begin{array}{c}-0.0145^{* * *} \\
(0.0028)\end{array}$ & & $\begin{array}{c}0.0115 \\
(0.1749)\end{array}$ & $\begin{array}{l}-0.0611^{*} \\
(0.0528)\end{array}$ & $\begin{array}{c}0.0582 * * * \\
(<0.0001)\end{array}$ & $\begin{array}{l}-0.0153 \\
(0.2401)\end{array}$ & & $\begin{array}{c}0.4029 * * * \\
(<0.0001)\end{array}$ & & 326 & $43.75 \%$ \\
\hline$T U R N$ & $\begin{array}{c}0.2614 * * * \\
(0.0021)\end{array}$ & $\begin{array}{c}0.0093 * * * \\
(0.0098)\end{array}$ & $\begin{array}{c}-0.0104 * * \\
(0.0238)\end{array}$ & & $\begin{array}{c}0.0077 \\
(0.3436)\end{array}$ & $\begin{array}{l}-0.0485 \\
(0.1094)\end{array}$ & $\begin{array}{c}0.0479 * * * \\
(0.0001)\end{array}$ & $\begin{array}{l}-0.0112 \\
(0.3694)\end{array}$ & & & $\begin{array}{l}0.3737 * * * \\
(<0.0001)\end{array}$ & 326 & $48.14 \%$ \\
\hline$A M I H$ & $\begin{array}{c}6.6534 * * * \\
(0.0002)\end{array}$ & $\begin{array}{c}0.1522 * * \\
(0.0437)\end{array}$ & $\begin{array}{c}-0.2507 * * \\
(0.0100)\end{array}$ & & $\begin{array}{c}-0.6473 * * * \\
(0.0002)\end{array}$ & $\begin{array}{c}1.0083 \\
(0.1134)\end{array}$ & $\begin{array}{l}-0.3122 \\
(0.2363)\end{array}$ & $\begin{array}{c}0.0397 \\
(0.8794)\end{array}$ & $\begin{array}{c}-1.1886 * \\
(0.0766)\end{array}$ & & & 326 & $14.89 \%$ \\
\hline$A M I H$ & $\begin{array}{c}6.5624 * * * \\
(0.0003)\end{array}$ & $\begin{array}{l}0.1457 * \\
(0.0527)\end{array}$ & $\begin{array}{c}-0.2429 * * * \\
(0.0132)\end{array}$ & & $\begin{array}{c}-0.6600 * * * \\
(0.0001)\end{array}$ & $\begin{array}{c}1.0412 \\
(0.1022)\end{array}$ & $\begin{array}{l}-0.3183 \\
(0.2337)\end{array}$ & $\begin{array}{c}0.0470 \\
(0.8579)\end{array}$ & & $\begin{array}{l}-1.1277 \\
(0.1195)\end{array}$ & & 326 & $14.62 \%$ \\
\hline$A M I H$ & $\begin{array}{c}6.6393 * * * \\
(0.0002)\end{array}$ & $\begin{array}{c}0.1608 * * \\
(0.0336)\end{array}$ & $\begin{array}{c}-0.2548 * * * \\
(0.0087)\end{array}$ & & $\begin{array}{c}-0.6172 * * * \\
(0.0003)\end{array}$ & $\begin{array}{c}0.9545 \\
(0.1340)\end{array}$ & $\begin{array}{l}-0.3216 \\
(0.2199)\end{array}$ & $\begin{array}{c}0.0241 \\
(0.9265)\end{array}$ & & & $\begin{array}{c}-1.2848 * * \\
(0.0405)\end{array}$ & 326 & $14.97 \%$ \\
\hline$L \_O \_T$ & $\begin{array}{c}81.3530 * * * \\
(<0.0001)\end{array}$ & $\begin{array}{c}-2.8718^{* * *} \\
(<0.0001)\end{array}$ & $\begin{array}{c}-2.4016^{* * *} \\
(<0.0001)\end{array}$ & & $\begin{array}{l}-1.3090 \\
(0.1395)\end{array}$ & $\begin{array}{c}1.2586 \\
(0.7016)\end{array}$ & $\begin{array}{l}-2.1116 \\
(0.1214)\end{array}$ & $\begin{array}{l}-1.8020 \\
(0.1831)\end{array}$ & $\begin{array}{c}-11.3078 * * * \\
\quad(0.0012)\end{array}$ & & & 326 & $29.39 \%$ \\
\hline$L \_O \_T$ & $\begin{array}{c}80.3132 * * * \\
(<0.0001)\end{array}$ & $\begin{array}{c}-2.9157 * * * \\
(<0.0001)\end{array}$ & $\begin{array}{c}-2.3272 * * * \\
(<0.0001)\end{array}$ & & $\begin{array}{l}-1.3326 \\
(0.1330)\end{array}$ & $\begin{array}{c}1.3969 \\
(0.6703)\end{array}$ & $\begin{array}{l}-2.3910^{*} \\
(0.0834)\end{array}$ & $\begin{array}{l}-1.7345 \\
(0.2010)\end{array}$ & & $\begin{array}{c}-11.6845^{* * *} \\
(0.0019)\end{array}$ & & 326 & $29.33 \%$ \\
\hline$L \_O \_T$ & $\begin{array}{c}81.2650 * * * \\
(<0.0001)\end{array}$ & $\begin{array}{c}-2.8347 * * * \\
(<0.0001)\end{array}$ & $\begin{array}{c}-2.4266^{* * *} \\
(<0.0001)\end{array}$ & & $\begin{array}{l}-1.1904 \\
(0.1741)\end{array}$ & $\begin{array}{c}1.0827 \\
(0.7402)\end{array}$ & $\begin{array}{l}-1.9940 \\
(0.1388)\end{array}$ & $\begin{array}{l}-1.7331 \\
(0.1966)\end{array}$ & & & $\begin{array}{c}-11.3373 * * * \\
(0.0005)\end{array}$ & 326 & $30.32 \%$ \\
\hline$Q S$ & $\begin{array}{l}5.5929 * * * \\
(<0.0001)\end{array}$ & $\begin{array}{c}0.3759^{* * * *} \\
(<0.0001)\end{array}$ & & $\begin{array}{c}-0.3318 * * * \\
(<0.0001)\end{array}$ & $\begin{array}{c}-0.2011 * \\
(0.0873)\end{array}$ & $\begin{array}{c}0.5795 \\
(0.1132)\end{array}$ & $\begin{array}{c}-0.3905 * * \\
(0.0248)\end{array}$ & $\begin{array}{l}-0.2161 \\
(0.1699)\end{array}$ & $\begin{array}{c}-1.1526^{* * *} \\
(0.0032)\end{array}$ & & & 154 & $52.64 \%$ \\
\hline$Q S$ & $\begin{array}{l}5.6004 * * * \\
(<0.0001)\end{array}$ & $\begin{array}{c}0.3671 * * * \\
(<0.0001)\end{array}$ & & $\begin{array}{c}-0.3285^{* * *} \\
(<0.0001)\end{array}$ & $\begin{array}{l}-0.2104 * \\
(0.0752)\end{array}$ & $\begin{array}{l}0.6223 * \\
(0.0904)\end{array}$ & $\begin{array}{c}-0.3951 * * \\
(0.0258)\end{array}$ & $\begin{array}{l}-0.2158 \\
(0.1722)\end{array}$ & & $\begin{array}{c}-1.1648 * * * \\
(0.0069)\end{array}$ & & 154 & $52.22 \%$ \\
\hline$Q S$ & $\begin{array}{l}5.4767 * * * \\
(<0.0001)\end{array}$ & $\begin{array}{c}0.3791 * * * \\
(<0.0001)\end{array}$ & & $\begin{array}{c}-0.3236 * * * \\
(<0.0001)\end{array}$ & $\begin{array}{l}-0.1958^{*} \\
(0.0945)\end{array}$ & $\begin{array}{c}0.5272 \\
(0.1511)\end{array}$ & $\begin{array}{c}-0.3991 * * \\
(0.0207)\end{array}$ & $\begin{array}{l}-0.2043 \\
(0.1970)\end{array}$ & & & $\begin{array}{c}-1.1214^{* * *} \\
(0.0021)\end{array}$ & 154 & $52.79 \%$ \\
\hline$E S$ & $\begin{array}{l}4.5359 * * * \\
(<0.0001)\end{array}$ & $\begin{array}{c}0.2761 * * * \\
(<0.0001)\end{array}$ & & $\begin{array}{c}-0.2793 * * * \\
(<0.0001)\end{array}$ & $\begin{array}{l}-0.1055 \\
(0.2444)\end{array}$ & $\begin{array}{c}0.4366 \\
(0.1227)\end{array}$ & $\begin{array}{l}-0.2549 * \\
(0.0574)\end{array}$ & $\begin{array}{l}-0.1957 \\
(0.1082)\end{array}$ & $\begin{array}{c}-0.9308 * * * \\
(0.0021)\end{array}$ & & & 154 & $53.09 \%$ \\
\hline$E S$ & $\begin{array}{l}4.5255^{* * * *} \\
(<0.0001)\end{array}$ & $\begin{array}{l}0.2693 * * * \\
(<0.0001)\end{array}$ & & $\begin{array}{c}-0.2756^{* * *} \\
(<0.0001)\end{array}$ & $\begin{array}{l}-0.1104 \\
(0.2253)\end{array}$ & $\begin{array}{c}0.4644 \\
(0.1017)\end{array}$ & $\begin{array}{l}-0.2635^{*} \\
(0.0536)\end{array}$ & $\begin{array}{l}-0.1949 \\
(0.1107)\end{array}$ & & $\begin{array}{c}-0.9694 * * * \\
(0.0037)\end{array}$ & & 154 & $52.79 \%$ \\
\hline
\end{tabular}




\begin{tabular}{|c|c|c|c|c|c|c|c|c|c|c|c|c|}
\hline$E S$ & $\begin{array}{c}4.4823^{* * *} \\
(<0.0001)\end{array}$ & $\begin{array}{c}0.2785^{* * *} \\
(<0.0001)\end{array}$ & $\begin{array}{c}-0.2757 * * * \\
(<0.0001)\end{array}$ & $\begin{array}{l}-0.1036 \\
(0.2512)\end{array}$ & $\begin{array}{c}0.4038 \\
(0.1547)\end{array}$ & $\begin{array}{c}-0.2560^{*} \\
(0.0541)\end{array}$ & $\begin{array}{l}-0.1889 \\
(0.1232)\end{array}$ & & & $\begin{array}{c}-0.8943 * * * \\
(0.0015)\end{array}$ & 154 & $53.29 \%$ \\
\hline$R S$ & $\begin{array}{l}1.5215^{* * * *} \\
(<0.0001)\end{array}$ & $\begin{array}{c}0.1016^{* * * *} \\
(<0.0001)\end{array}$ & $\begin{array}{c}-0.0935^{* * *} * \\
(<0.0001)\end{array}$ & $\begin{array}{l}-0.0303 \\
(0.4418)\end{array}$ & $\begin{array}{c}0.1653 \\
(0.1777)\end{array}$ & $\begin{array}{c}-0.1492 * * \\
(0.0109)\end{array}$ & $\begin{array}{l}-0.0716 \\
(0.1760)\end{array}$ & $\begin{array}{c}-0.3730^{* * *} \\
(0.0045)\end{array}$ & & & 153 & $43.21 \%$ \\
\hline$R S$ & $\begin{array}{l}1.5188^{* * * *} \\
(<0.0001)\end{array}$ & $\begin{array}{c}0.0989^{* * *} \\
(<0.0001)\end{array}$ & $\begin{array}{c}-0.0921 * * * \\
(<0.0001)\end{array}$ & $\begin{array}{l}-0.0324 \\
(0.4126)\end{array}$ & $\begin{array}{c}0.1767 \\
(0.1507)\end{array}$ & $\begin{array}{c}-0.1522 * * \\
(0.0107)\end{array}$ & $\begin{array}{c}-0.0712 \\
(0.1792)\end{array}$ & & $\begin{array}{c}-0.3890^{* * * *} \\
(0.0070)\end{array}$ & & 153 & $42.92 \%$ \\
\hline$R S$ & $\begin{array}{l}1.4880^{* * *} \\
(<0.0001)\end{array}$ & $\begin{array}{l}0.1025^{* * *} \\
(<0.0001)\end{array}$ & $\begin{array}{c}-0.0912 * * * \\
(<0.0001)\end{array}$ & $\begin{array}{l}-0.0288 \\
(0.4632)\end{array}$ & $\begin{array}{c}0.1495 \\
(0.2245)\end{array}$ & $\begin{array}{c}-0.1509 * * * \\
(0.0094)\end{array}$ & $\begin{array}{l}-0.0676 \\
(0.2036)\end{array}$ & & & $\begin{array}{c}-0.3608^{* * *} \\
(0.0031)\end{array}$ & 153 & $43.45 \%$ \\
\hline
\end{tabular}

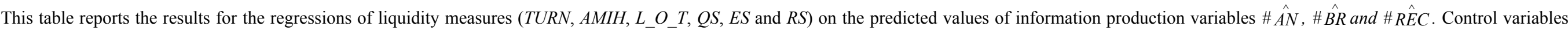

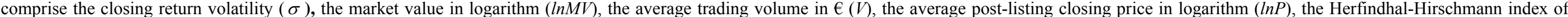

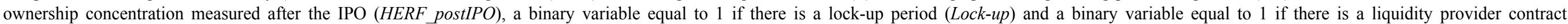
(LP_contract). ***,**,* indicate that the coefficient is significantly positive or negative, respectively, at the 1,5 , and $10 \%$ level; $p$-values are reported in brackets. 
Table 6. Impact of predicted analyst coverage on information asymmetry

\begin{tabular}{|c|c|c|c|c|c|c|c|c|c|c|c|c|}
\hline & $\alpha_{l s b}$ & $\alpha_{l s b}$ & $\alpha_{l s b}$ & PIMP & PIMP & PIMP & $P I N$ & PIN & PIN & AdjPIN & AdjPIN & AdjPIN \\
\hline Intercept & $\begin{array}{l}1.5096 * * * \\
(<0.0001)\end{array}$ & $\begin{array}{l}1.5012 * * * \\
(<0.0001)\end{array}$ & $\begin{array}{l}1.5458 * * * \\
(<0.0001)\end{array}$ & $\begin{array}{c}0.7317 * * * \\
(<0.0001)\end{array}$ & $\begin{array}{c}0.7292 * * * \\
(<0.0001)\end{array}$ & $\begin{array}{c}0.7390 * * * \\
(<0.0001)\end{array}$ & $\begin{array}{c}-0.1950 \\
(0.2381)\end{array}$ & $\begin{array}{c}-0.1989 \\
(0.2275)\end{array}$ & $\begin{array}{c}-0.1974 \\
(0.2282)\end{array}$ & $\begin{array}{c}-0.0363 \\
(0.8075)\end{array}$ & $\begin{array}{c}-0.0360 \\
(0.8089)\end{array}$ & $\begin{array}{c}-0.0306 \\
(0.8365)\end{array}$ \\
\hline$\sigma$ & $\begin{array}{c}0.0358^{* *} \\
(0.0291)\end{array}$ & $\begin{array}{c}0.0360^{* *} \\
(0.0278)\end{array}$ & $\begin{array}{c}0.0353^{* *} \\
(0.0317)\end{array}$ & $\begin{array}{c}0.0293 * * * \\
(<0.0001)\end{array}$ & $\begin{array}{c}0.0292 * * * \\
(<0.0001)\end{array}$ & $\begin{array}{c}0.0289 * * * \\
(<0.0001)\end{array}$ & $\begin{array}{c}-0.0089 \\
(0.2426)\end{array}$ & $\begin{array}{c}-0.0088 \\
(0.2453)\end{array}$ & $\begin{array}{l}-0.0089 \\
(0.2413)\end{array}$ & $\begin{array}{c}-0.0107 \\
(0.1207)\end{array}$ & $\begin{array}{c}-0.0107 \\
(0.1216)\end{array}$ & $\begin{array}{l}-0.0109 \\
(0.1143)\end{array}$ \\
\hline $\ln M V$ & $\begin{array}{c}-0.0574 * * * \\
(0.0017)\end{array}$ & $\begin{array}{c}-0.0568 * * * \\
(0.0018)\end{array}$ & $\begin{array}{c}-0.0586^{* * *} \\
(0.0014)\end{array}$ & $\begin{array}{c}-0.0248^{* * * *} \\
(0.0005)\end{array}$ & $\begin{array}{c}-0.0245^{* * *} * \\
(0.0006)\end{array}$ & $\begin{array}{c}-0.0252 * * * \\
(0.0004)\end{array}$ & $\begin{array}{c}0.0236^{* * *} \\
(0.0057)\end{array}$ & $\begin{array}{c}0.0238 * * * \\
(0.0049)\end{array}$ & $\begin{array}{c}0.0234 * * * \\
(0.0058)\end{array}$ & $\begin{array}{c}0.0114 \\
(0.1377)\end{array}$ & $\begin{array}{c}0.0114 \\
(0.1341)\end{array}$ & $\begin{array}{c}0.0110 \\
(0.1486)\end{array}$ \\
\hline $\ln P$ & $\begin{array}{c}-0.0625^{*} \\
(0.0756)\end{array}$ & $\begin{array}{c}-0.0604^{*} \\
(0.0859)\end{array}$ & $\begin{array}{c}-0.0666^{*} \\
(0.0592)\end{array}$ & $\begin{array}{c}-0.0411^{* * *} \\
(0.0029)\end{array}$ & $\begin{array}{c}-0.0406^{* * *} \\
(0.0033)\end{array}$ & $\begin{array}{c}-0.0412 * * * \\
(0.0028)\end{array}$ & $\begin{array}{c}0.0082 \\
(0.6250)\end{array}$ & $\begin{array}{c}0.0090 \\
(0.5925)\end{array}$ & $\begin{array}{c}0.0104 \\
(0.5345)\end{array}$ & $\begin{array}{c}0.0249 \\
(0.1026)\end{array}$ & $\begin{array}{c}0.0253 * \\
(0.0969)\end{array}$ & $\begin{array}{c}0.0252 * \\
(0.0987)\end{array}$ \\
\hline$M A N \_$postIPO & $\begin{array}{l}-0.0637 \\
(0.4001)\end{array}$ & $\begin{array}{l}-0.0647 \\
(0.3917)\end{array}$ & $\begin{array}{l}-0.0720 \\
(0.3426)\end{array}$ & $\begin{array}{c}0.0200 \\
(0.4967)\end{array}$ & $\begin{array}{c}0.0195 \\
(0.5077)\end{array}$ & $\begin{array}{c}0.0172 \\
(0.5597)\end{array}$ & $\begin{array}{c}0.0427 \\
(0.2284)\end{array}$ & $\begin{array}{c}0.0425 \\
(0.2294)\end{array}$ & $\begin{array}{c}0.0411 \\
(0.2437)\end{array}$ & $\begin{array}{c}0.0253 \\
(0.4288)\end{array}$ & $\begin{array}{c}0.0246 \\
(0.4414)\end{array}$ & $\begin{array}{c}0.0234 \\
(0.4639)\end{array}$ \\
\hline$N M$ & $\begin{array}{c}-0.0765 \\
(0.1800)\end{array}$ & $\begin{array}{c}-0.0976 \\
(0.1017)\end{array}$ & $\begin{array}{c}-0.0639 \\
(0.2538)\end{array}$ & $\begin{array}{c}0.0004 \\
(0.9862)\end{array}$ & $\begin{array}{c}-0.0097 \\
(0.6741)\end{array}$ & $\begin{array}{c}0.0066 \\
(0.7610)\end{array}$ & $\begin{array}{c}0.0555^{* *} \\
(0.0371)\end{array}$ & $\begin{array}{c}0.0489^{*} \\
(0.0781)\end{array}$ & $\begin{array}{c}0.0576^{* *} \\
(0.0265)\end{array}$ & $\begin{array}{c}0.0266 \\
(0.2665)\end{array}$ & $\begin{array}{c}0.0215 \\
(0.3918)\end{array}$ & $\begin{array}{c}0.0296 \\
(0.2072)\end{array}$ \\
\hline NTIC & $\begin{array}{c}-0.0718 \\
(0.1769)\end{array}$ & $\begin{array}{l}-0.0705 \\
(0.1833)\end{array}$ & $\begin{array}{c}-0.0710 \\
(0.1834)\end{array}$ & $\begin{array}{c}0.0004 \\
(0.9860)\end{array}$ & $\begin{array}{c}0.0012 \\
(0.9544)\end{array}$ & $\begin{array}{c}-0.0005 \\
(0.9800)\end{array}$ & $\begin{array}{c}-0.0084 \\
(0.7357)\end{array}$ & $\begin{array}{c}-0.0082 \\
(0.7425)\end{array}$ & $\begin{array}{l}-0.0096 \\
(0.7006)\end{array}$ & $\begin{array}{c}-0.0119 \\
(0.5947)\end{array}$ & $\begin{array}{c}-0.0114 \\
(0.6090)\end{array}$ & $\begin{array}{c}-0.0122 \\
(0.5865)\end{array}$ \\
\hline$\# \hat{A} N$ & $\begin{array}{c}-0.3463 * * * \\
(0.0048)\end{array}$ & & & $\begin{array}{c}-0.1808^{* * *} \\
(0.0002)\end{array}$ & & & $\begin{array}{c}-0.1057 * \\
(0.0645)\end{array}$ & & & $\begin{array}{c}-0.0851 * \\
(0.0986)\end{array}$ & & \\
\hline$\# \hat{B R}$ & & $\begin{array}{c}-0.3990 * * * \\
(0.0038)\end{array}$ & & & $\begin{array}{c}-0.2048 * * * \\
(0.0002)\end{array}$ & & & $\begin{array}{c}-0.1214^{*} \\
(0.0592)\end{array}$ & & & $\begin{array}{c}-0.0987 * \\
(0.0890)\end{array}$ & \\
\hline$\# \hat{R} E C$ & & & $\begin{array}{c}-0.3184 * * * \\
(0.0048)\end{array}$ & & & $\begin{array}{c}-0.1672 * * * \\
(0.0002)\end{array}$ & & & $\begin{array}{c}-0.1044 * * \\
(0.0462)\end{array}$ & & & $\begin{array}{c}-0.0806^{*} \\
(0.0882)\end{array}$ \\
\hline \# obs. & 153 & 153 & 153 & 153 & 153 & 153 & 148 & 148 & 148 & 150 & 150 & 150 \\
\hline$R^{2}$ & $18.95 \%$ & $19.29 \%$ & $18.46 \%$ & $45.45 \%$ & $45.51 \%$ & $45.39 \%$ & $14.02 \%$ & $14.22 \%$ & $14.79 \%$ & $9.19 \%$ & $9.27 \%$ & $9.22 \%$ \\
\hline
\end{tabular}

This table displays the estimations for the regressions of information asymmetry measures $\left(\alpha_{l s b}, P I M P, P I N\right.$ and $\left.A d j P I N\right)$ on the predicted values of information production variables $\# \hat{A} N$, \# $\hat{B R}$ and $\# R \hat{E} C$. Control variables comprise the closing return volatility $(\sigma)$, the market value in logarithm $(\ln M V)$, the average post-listing closing price in logarithm $(\ln P)$, the managers' holdings after the IPO $\left(M A N \_\right.$postIPO), a binary variable equal to 1 for New Market or Alternext issues $(N M)$ and a binary variable equal to 1 for new technologies firms $(N T I C)$. $* * *, * * *$ indicate that the coefficient is significantly positive or negative, respectively, at the 1,5 , and $10 \%$ level; $p$-values are reported in brackets. 
Table 7. Estimation of initial underpricing probability

\begin{tabular}{cccccccccc}
\hline & Intercept & MAN_preIPO & VC & SaleRatio & $H M$ & LP_contract & REP & $\#$ obs. & $R^{2}$ \\
\hline$P\left(U_{1 w}>0\right)$ & 1.2129 & 0.3492 & $-0.3357^{* *}$ & -0.8849 & -0.1469 & $0.3232 * *$ & 0.0576 & 326 & $9.73 \%$ \\
& $(0.0027)$ & $(0.1296)$ & $(0.0386)$ & $(0.1017)$ & $(0.1274)$ & $(0.0371)$ & $(0.2446)$ & & \\
\hline
\end{tabular}

This table reports the results of the first stage logit regression (of the three stage analysis) in which the dependant variable is a dummy equal to 1 if the issue is underpriced, 0 otherwise. The probability of an issue to be underpriced is modeled as a function of the pre-IPO managers' shareholdings (MAN_preIPO), a binary variable equal to 1 if the firm is VC-backed $(V C)$, the ratio of the number of shares sold in the IPO divided by the number of outstanding shares following the IPO (Saleratio), the number of IPOs over the preceding 3 months in logarithm $(H M)$, a binary variable equal to 1 if there is a liquidity provider contract (LP_contract) and REP is the market share of all lead underwriters for the IPO (in logarithm) . ***,*** indicate that the coefficient is significantly positive or negative, respectively, at the 1,5 , and $10 \%$ level; $p$-values are reported in brackets. 